\title{
THE METHOD DEVELOPMENT OF ANALYSIS Cd, Cu, Pb AND Zn IN SEA WATER BY ADSORPTIVE STRIPPING VOLTAMMETRY (ASV) IN THE PRESENCE OF CALCON AS COMPLEXING AGENT
}

\author{
Deswati ${ }^{*}$, Hamzar Suyani, and Safni \\ Department of Chemistry, Faculty of Mathematics and Natural Sciences, \\ Andalas University, Kampus Unand Limau Manis Padang, 25163
}

Received November 22, 2011; Accepted January 28, 2012

\begin{abstract}
A sensitive and selective adsorptive stripping voltammetric (AdSV) method to determine $\mathrm{Cd}(\mathrm{II}), \mathrm{Cu}(\mathrm{II}), \mathrm{Pb}(\mathrm{II})$ and $\mathrm{Zn}(\mathrm{II})$ in sea water is proposed. The aim of this study was to get optimum condition for the determination of $\mathrm{Cd}(\mathrm{II}), \mathrm{Cu}(\mathrm{II}), \mathrm{Pb}(\mathrm{II})$ and $\mathrm{Zn}(\mathrm{II})$. Adsorptive stripping voltammetry has been used for ultra trace determination of $\mathrm{Cd}(\mathrm{II}), \mathrm{Cu}(\mathrm{II}), \mathrm{Pb}(\mathrm{II})$ and $\mathrm{Zn}(\mathrm{II})$ using calcon as a complexing agent (ligand). In this case, the optimum conditions were reached at $0.1 \mathrm{M} \mathrm{KCl}$ supporting electrolyte, concentration of $0.5 \mathrm{mM}$ calcon for $\mathrm{Cd}(\mathrm{II}), \mathrm{Cu}(\mathrm{II}) 0.3 \mathrm{mM}$ while $0.7 \mathrm{mM}$ for $\mathrm{Pb}(\mathrm{II})$ and $\mathrm{Zn}(\mathrm{II}), \mathrm{pH} 6$ for $\mathrm{Cu}(\mathrm{II})$ and $\mathrm{pH} 7$ for $\mathrm{Cd}(\mathrm{II}), \mathrm{Pb}(\mathrm{II})$ and $\mathrm{Zn}(\mathrm{II})$, accumulation potential $-0.5 \mathrm{~V}$ for $\mathrm{Cu}(\mathrm{II})$ and $\mathrm{Pb}(\mathrm{II})$ and $-0.6 \mathrm{~V}$ for $\mathrm{Cd}(\mathrm{II})$ and $\mathrm{Zn}$ (II) and accumulation time 70 sec for $\mathrm{Cd}(\mathrm{II}), 90$ sec for $\mathrm{Cu}$ (II) and $\mathrm{Pb}$ (II) while $50 \mathrm{~s}$ for $\mathrm{Zn}(\mathrm{II})$. At the optimum condition the relative standard deviations were $7.80 \%, 4.25 \%, 8.70 \%$ and $0.86 \%$ for $\mathrm{Cd}(\mathrm{II}), \mathrm{Cu}(\mathrm{II}), \mathrm{Pb}(\mathrm{II})$ and $\mathrm{Zn}(\mathrm{II})$ respectively for eight replicates ( $n=8)$ measurements of $10 \mu \mathrm{g} / \mathrm{L} \mathrm{Cd}(\mathrm{II})$, $\mathrm{Cu}(I I), \mathrm{Pb}(\mathrm{II})$ and $\mathrm{Zn}(\mathrm{II})$. The method was applied for the direct determination of $\mathrm{Cd}(\mathrm{II}), \mathrm{Cu}(\mathrm{II}), \mathrm{Pb}(\mathrm{II})$ and $\mathrm{Zn}(\mathrm{II})$ in sea water around Bungus, Padang City. Concentration Cd(II), Cu(II), Pb(II) and Zn(II) in sample were $13.200 \mu \mathrm{g} / \mathrm{L}$ for $\mathrm{Cd}(\mathrm{II}), 17.200 \mu \mathrm{g} / \mathrm{L}$ for $\mathrm{Cu}(\mathrm{II}), 0.089 \mu \mathrm{g} / \mathrm{L}$ for $\mathrm{Pb}(\mathrm{II})$ and $62.000 \mu \mathrm{g} / \mathrm{L}$ for $\mathrm{Zn}(\mathrm{II})$ with recovery of $98.68 \%, 97.99 \%$, 96.17\% and 99.96\% for $\mathrm{Cd}(I I), \mathrm{Cu}(I I), \mathrm{Pb}(\mathrm{II})$ and $\mathrm{Zn}(\mathrm{II})$, respectively.
\end{abstract}

Keywords: trace metal analysis; calcon; sea water; adsorptive stripping voltammetry

\section{ABSTRAK}

Metoda selektif dan sensitif penentuan $\mathrm{Cd}(\mathrm{II}), \mathrm{Cu}(\mathrm{II}), \mathrm{Pb}(\mathrm{II})$ dan $\mathrm{Zn}(\mathrm{II})$ dalam air laut secara voltammetri stripping adsorptif telah dilakukan. Tujuan dari penelitian ini adalah untuk mendapatkan kondisi optimum Cd(II), $\mathrm{Cu}(I I), \mathrm{Pb}(\mathrm{II})$ dan $\mathrm{Zn}(\mathrm{II})$. Voltammetri stripping adsorptif telah digunakan untuk penentuan ultra runut $\mathrm{Cd}(\mathrm{II}), \mathrm{Cu}(\mathrm{II})$, $\mathrm{Pb}(\mathrm{II})$ and $\mathrm{Zn}(\mathrm{II})$ dengan menggunakan kalkon sebagai pengompleks (ligand). Dari hasil penelitian ini, didapatkan kondisi optimum yaitu $\mathrm{KCl}$ 0,1 M sebagai elektrolit pendukung, konsentrasi kalkon untuk $\mathrm{Cd}$ (II) 0,5 mM, Cu(II) 0,3 $\mathrm{mM}$ sedangkan untuk $\mathrm{Pb}(\mathrm{II})$ dan $\mathrm{Zn}(\mathrm{II})$ 0,7 mM, pH 6 untuk $\mathrm{Cu}(\mathrm{II})$ dan $\mathrm{pH} 7$ untuk $\mathrm{Cd}(\mathrm{II}), \mathrm{Pb}(\mathrm{II})$ dan $\mathrm{Zn}(\mathrm{II})$, potensial akumulasi -0,5 Volt untuk $\mathrm{Cu}$ (II) dan $\mathrm{Pb}$ (II) dan -0,6 Volt untuk for $\mathrm{Cd}(\mathrm{II})$ dan $\mathrm{Zn}(\mathrm{II})$ dan waktu akumulasi untuk Cd(II) 70 detik, untuk Cu(II) dan Pb(II) 90 detik sedangkan untuk Zn(II) 50 detik, Pada kondisi optimum tersebut diperoleh standar deviasi relatif dengan delapan kali pengulangan $(n=8)$, pada pengukuran masing-masing larutan standar $\mathrm{Cd}(\mathrm{II}), \mathrm{Cu}(\mathrm{II}), \mathrm{Pb}(\mathrm{II})$ dan $\mathrm{Zn}(\mathrm{II}) 10 \mu \mathrm{g} / \mathrm{L}$ adalah : 7,8\%, 4,25\%, 8,70\% dan 0,86\%. Metoda ini diaplikasikan untuk penentuan $\mathrm{Cd}(\mathrm{II}), \mathrm{Cu}(\mathrm{II}), \mathrm{Pb}(\mathrm{II})$ dan $\mathrm{Zn}(\mathrm{II})$ secara lansung dalam air laut sekitar Bungus, Kota Padang. Konsentrasi sampel yang diperoleh adalah : 13,200 $\mu \mathrm{g} / \mathrm{L}$ untuk Cd(II), 17,200 $\mu \mathrm{g} / \mathrm{L}$ untuk Cu(II), 0,089 $\mu \mathrm{g} / \mathrm{L}$ untuk $\mathrm{Pb}(\mathrm{II})$ dan 62,000 $\mu \mathrm{g} / \mathrm{L}$ untuk $\mathrm{Zn}(\mathrm{II})$, dengan nilai perolehan kembali (recovery) untuk masing-masing $\mathrm{Cd}(\mathrm{II}), \mathrm{Cu}(\mathrm{II})$, $\mathrm{Pb}(\mathrm{II})$ and $\mathrm{Zn}(\mathrm{II})$ adalah : 98,68\%, 97,99\%, 96,17\% dan $99.96 \%$.

Kata Kunci: analisis logam runut; logam berat; air laut; voltammetri stripping adsorptif

\section{INTRODUCTION}

The development of industrial sector in a variety of coastal and marine areas is increasing, so more and more environment pollution caused problems. Pollution occurs in coastal areas and marine waters due to a decrease in its support because of variety of human

* Corresponding author. Tel/Fax : +62-751-462193

Email address : deswati_ua@yahoo.co.id activities so that living organisms in the waters are affected. One form of pollution that occurs in marine waters is in the form of heavy metals such as $\mathrm{Hg}, \mathrm{Cu}$, $\mathrm{Cd}, \mathrm{Cr}, \mathrm{Pb}, \mathrm{Fe}, \mathrm{Zn}$ and $\mathrm{Ni}$ [1]. At certain concentration, the presence of heavy metals in water may cause pollution to the waters. 
Heavy metal that naturally found in sea water is very low, that ranges between $10^{-5}-10^{-2} \mathrm{mg} / \mathrm{L}$, while the matrix samples (salinity) is quite high [2]. Various analytical methods have been widely used for the determination of metals such as: potentiometry using ion selective electrodes, atomic absorption spectrophotometry, polarography but, these methods are not able to measure the metal ions at very small concentration, although they have previously been done pre-concentration by solvent extraction [3]. Thus it needs an alternative method that can overcome the above problems. Adsorptive stripping voltammetry was selected as an alternative method of analysis due to its high sensitivity, low detection limit in $\mu \mathrm{g} / \mathrm{L}$ level, simple and easy sample preparation. In adsorptive stripping voltammetry pre-concentration time is short, generally less than 1 min [4-6].

Adsorptive stripping voltammetry is one of the stripping voltammetry method that is widely used in the determination of heavy metals because it has a good sensitivity, metals with very small concentrations can be determined [6-7]. The method consists of several steps, namely: 1) formation of metal complexes with ligand; 2) absorption of complexes on the electrode surface, and 3) measurement of currents with potential scan the anode or cathode. The total accumulated metal is proportional to the time given $[6,8]$.

The purpose of this technique is to create a more selective analysis and lower detection limit. Selectivity can be improved by selecting a suitable complexing agent (ligand) and supporting electrolyte [8]. Ligand is a substance that contains one or more free electron pairs that can act as an electron donor in the formation of complex compounds with metal ions. Ligand has a variety of functional groups that can interact with metal ions. Various types of ligands have been used in this research, among others: ammonium pyrrolidine dithiocarbamate (APDC), dimethyl glyoxime (DMG), oxine (8-hydroxy quinolin) and calcon. From the results of variations of ligand (complexing agent) studied, calcon showed a better complexing agent because it provides the highest peak current [9].

Calcon has $\mathrm{C}_{20} \mathrm{H}_{13} \mathrm{~N}_{2} \mathrm{NaO}_{5} \mathrm{~S}$ molecular formula with IUPAC name of 2-hydroxy-1-(2-hydroxy-1-naphthylazo)naphthalen-4-sulfonic acid sodium salt, with a relative mass of $416.39 \mathrm{~g} / \mathrm{mol}$. This compound is a product of condensation reactions between benzaldehyde $\left(\mathrm{C}_{6} \mathrm{H}_{5} \mathrm{CHO}\right)$ and acetophenone $\left(\mathrm{C}_{6} \mathrm{H}_{5} \mathrm{COCH}_{3}\right)$. Calcon can also be considered as ketones, a group of benzalacetophenone derivative from natural $\mathrm{ArCOCH}=\mathrm{CHAr}$ with orange color, such as curcumin, erydictyol, hesperitin and maringinin. Utilization of calcon is associated with the group of (2-hydroxy-1 naphthylazo) in the structure. Calcon role as a complexing is supported by the free electron pair (lone pair electrons) from dihydroxyl group that can bind metal ions to form the metal-calcon complex [10].

Supporting electrolytes used in this research are $\mathrm{KCl}$ and $\mathrm{NH}_{4} \mathrm{Cl}$, which are required to suppress migration current, to control potential by reducing the resistance of the solution, to eliminate electromigration effects, and to maintain a constant ionic strength. Detection limit is lowered by increasing analyte concentration absorbed on electrode surface [8,11].

In previous research, adsorptive stripping voltammetric technique was used for the determination $\mathrm{Ni}(\mathrm{II})$ by using calcon [12]. The results obtained that optimum conditions for $\mathrm{Ni}$ (II) was at $\mathrm{pH} 11$ and calcon concentration of $15 \mu \mathrm{M}$. The method of adsorptive stripping voltammetry is highly sensitive and selective so that it can be used to determine the species in solution at very small concentration [14], where $\mathrm{Cr}(\mathrm{VI})$ complexed with 2,2-bipyridine at $10 \mu \mathrm{M}$ concentration, detection limit was $0.1692 \mu \mathrm{g} / \mathrm{L}$ at $\mathrm{pH} 5$ [15]. The advantages of this method are: high salinity of sea water samples did not interfere in the determination, selective, fast, simple, low running costs and can for the simultaneous determination of copper, bismuth and lead in the presence of thymolphthalexone [16] and simultaneous determination of Traces of cadmium and zinc by using 5-phenyl-1,2,4-triazol-3-tion (PTT) as complexes agent [17].

The problem of the research is that the presence of heavy metal ions $(\mathrm{Cd}, \mathrm{Cu}, \mathrm{Pb}$ and $\mathrm{Zn}$ ) in sea waters is very dangerous, because it is toxic that damage the environment and biotic life, if the presence exceeded the minimum threshold is prescribed. Known concentration of the metal ions in waters is very small, while the matrix concentration (salinity) is large enough.

Existing methods for determination of metal ions is Flame Atomic Absorption Spectrophotometry (AAS), but these methods is not able to measure metal ions at very small concentration. Although pre-concentration was conducted to reduce or eliminate the high concentration salt from sea water using solvent extraction methods, the high salt concentration in the sample still interferes with the process of atomization in flame atomic absorption spectrophotometer [3]. Methods for the determination of metal ions in sea water by adsorptive stripping voltammetry still did not obtain suitable conditions.

To overcome the problem mentioned above a better condition of adsorptive stripping voltammetry is needed to get a selective and sensitive method. The parameter studied were variations of supporting electrolyte $\left(\mathrm{KCl}\right.$ and $\left.\mathrm{NH}_{4} \mathrm{Cl}\right)$, selection of suitable complexing agent for each metal ion (calcon, APDC, DMG and oxine), variations of complexing agent concentration (calcon), variation of $\mathrm{pH}$ solution, 
accumulation potential and accumulation time. To determine the precision, accuracy and sensitivity of method, relative standard deviation (SDR), recovery and detection limit were determined. The method at optimum condition was applied for the determination of $\mathrm{Cd}(\mathrm{II})$, $\mathrm{Cu}(\mathrm{II}) \mathrm{Pb}(\mathrm{II})$ and $\mathrm{Zn}(\mathrm{II})$ in seawater around Bungus, Padang City.

\section{EXPERIMENTAL SECTION}

\section{Materials}

The materials used for this study were $\mathrm{Cd}\left(\mathrm{NO}_{3}\right)_{2}$, $\mathrm{Cu}\left(\mathrm{NO}_{3}\right)_{2}, \quad \mathrm{~Pb}\left(\mathrm{NO}_{3}\right)_{2}, \quad \mathrm{Zn}\left(\mathrm{NO}_{3}\right)_{2}, \quad \mathrm{KCl}, \quad \mathrm{NH}_{4} \mathrm{Cl}$, concentrated $\mathrm{HCl}$, concentrated $\mathrm{HNO}_{3}$, acetate buffer, calcon, methanol, APDC, DMG, oxine, $\mathrm{NH}_{4} \mathrm{OH}$, sea water, Whatman filter paper, doubly distilled water and nitrogen gas.

\section{Instrumentation}

The instrument used in this study were 797 Computerace with Metrohm HMDE working electrode, a reference electrode $\mathrm{Ag} / \mathrm{AgCl} / \mathrm{KCl} 3 \mathrm{M}$, and the $\mathrm{Pt}$ electrode as a counter electrode; $\mathrm{pH}$ meter model 80 Griffin (Griffin \& George Loughborough, UK), analytical balance Mettler AE 200, Toledo, OH, USA; and glassware commonly used in laboratory.

\section{Procedure}

Variations in supporting electrolyte $\left(\mathrm{KCl}\right.$ and $\left.\mathrm{NH}_{4} \mathrm{Cl}\right)$

A total of $10 \mathrm{~mL}$ of standard solution of $\mathrm{Cd}(\mathrm{II})$ $10 \mu \mathrm{g} / \mathrm{L}, 0.5 \mathrm{~mL}$ of $0.1 \mathrm{M} \mathrm{KCl}$ and $0.3 \mathrm{~mL}$ of $1 \mathrm{mM}$ calcon was put into the voltammetric vessel. Potential was adjusted to $-0.7 \mathrm{~V}$, accumulation time of $60 \mathrm{sec}$ at $\mathrm{pH} 7$. Measurement performed to obtain the value of the peak current (Ip), the same was also done against $0.1 \mathrm{M}$ $\mathrm{NH}_{4} \mathrm{Cl}$. The curve between peak current and concentration of supporting electrolyte $(\mathrm{KCl}$ and $\mathrm{NH} 4 \mathrm{Cl})$ was constructed to determine the optimum supporting electrolyte. The same experiments was performed on $\mathrm{Cu}(\mathrm{II}), \mathrm{Pb}(\mathrm{II}), \mathrm{Zn}(\mathrm{II})$. From the results of these studies it was found that the optimum supporting electrolyte was $\mathrm{KCl}$.

\section{Variations of Complexing agent}

Into the vessel of voltammetric, it was put $10 \mathrm{~mL}$ of standard solution of $10 \mu \mathrm{g} / \mathrm{L} \mathrm{Cd}(\mathrm{II}), 0.5 \mathrm{~mL}$ of $0.1 \mathrm{M} \mathrm{KCl}$ was added, $\mathrm{pH}$ was adjusted to 7 , then added a variety of complexes, among others: calcon, APDC, DMG and oxine at a certain concentration into the solution of a total volume of $20 \mathrm{~mL}$. Measurements were taken at the accumulation time of $60 \mathrm{sec}$. After measurement completed, the data in the form of the peak current value
(Ip) were generated. A curve between peak current and complexing agent was constructed to determine a suitable complexing agent for $\mathrm{Cd}(\mathrm{II})$. The same procedure were carried out for $\mathrm{Cu}(\mathrm{II}), \mathrm{Pb}(\mathrm{II})$ and $\mathrm{Zn}(\mathrm{II})$. From the results of this study the optimum complexing agent obtained for each metal ion was calcon. For subsequent studies, calcon was used as complex optimum.

\section{Variation of calcon concentration}

A total of $20 \mathrm{~mL}$ standard solution of $10 \mu \mathrm{g} / \mathrm{L}$ $\mathrm{Cd}(\mathrm{II})$ and $0.5 \mathrm{~mL}$ of $0.1 \mathrm{M} \mathrm{KCl}$ were put into the voltammetric vessel. Adjust accumulation potential to $0.7 \mathrm{~V}$, accumulation time of $60 \mathrm{sec}$ and $\mathrm{pH} 7$ by the addition of $\mathrm{NH}_{4} \mathrm{OH}$. Calcon was added as a complexing agent at a concentration of $0.1 \mathrm{mM}, 0.2 \mathrm{mM}, 0.3 \mathrm{mM}$, $0.4 \mathrm{mM}, 0.5 \mathrm{mM}, 0.6 \mathrm{mM}, 0.7 \mathrm{mM}, 0.8 \mathrm{mM}$ and $0.9 \mathrm{mM}$. Measurements performed to obtain the value of the peak current (Ip). A curve between the calcon concentration and the peak current (Ip) was constructed to determine the optimum concentration of calcon. The same thing was also done to $\mathrm{Cu}(\mathrm{II}), \mathrm{Pb}(\mathrm{II})$ and $\mathrm{Zn}(\mathrm{II})$.

\section{Variation of $\mathrm{pH}$}

A total of $20 \mathrm{~mL}$ standard solution of $10 \mu \mathrm{g} / \mathrm{L}$ $\mathrm{Cd}(\mathrm{II})$ and $0.5 \mathrm{~mL}$ of $0.1 \mathrm{M} \mathrm{KCl}$ put into the voltammetric vessel was adjusted to the $\mathrm{pH}$ at the range of $3-9$ by adding acetate buffer, then $0.3 \mathrm{~mL}$ calcon added at optimum concentration for each metal that has been obtained. It was adjusted the accumulation potential to $-0.7 \mathrm{~V}$ for $\mathrm{Cd}(\mathrm{II})$ and $\mathrm{Cu}(\mathrm{II})$ whereas the $-0.6 \mathrm{~V}$ for $\mathrm{Pb}(\mathrm{II})$ and $\mathrm{Zn}(\mathrm{II})$ and accumulation time of $60 \mathrm{sec}$. Measurements were performed to obtain the value of the peak current (Ip). A curve between $\mathrm{pH}$ variation and the peak current (Ip) was constructed to determine the optimum $\mathrm{pH}$ measurements.

\section{Variation of potential accumulation}

A total of $20 \mathrm{~mL}$ of standard solution of $10 \mu \mathrm{g} / \mathrm{L}$ $\mathrm{Cd}$ (II) and $0.5 \mathrm{~mL}$ of $0.1 \mathrm{M} \mathrm{KCl}$ were put into the voltammetric vessel. Then add $0.3 \mathrm{~mL}$ calcon the optimum concentration (the highest peak currents), $\mathrm{pH}$ optimum and the accumulation time $60 \mathrm{sec}$. After that the solution was measured by the variation of accumulation potential -0.3 to $-0.8 \mathrm{~V}$. Furthermore a curve between the peak current and accumulation potential (Ip) was constructed to determine the optimum accumulation potential. The same thing was also done to the $\mathrm{Cu}(\mathrm{II}), \mathrm{Pb}(\mathrm{II})$ and $\mathrm{Zn}(\mathrm{II})$.

\section{Variation of accumulation time}

A total of $20 \mathrm{~mL}$ standard solution of $10 \mu \mathrm{g} / \mathrm{L}$ $\mathrm{Cd}(\mathrm{II})$ and $0.5 \mathrm{~mL}$ of $0.1 \mathrm{M} \mathrm{KCl}$ were put into the 
voltammetric vessel, then added $0.3 \mathrm{~mL}$ calcon to the optimum concentration. Accumulation potential is set in accordance with the obtained optimum accumulation potential, the $\mathrm{pH}$ optimum. Measurements were performed to obtain the value of the peak current (Ip). A curve between variation times of accumulation with peak current (Ip) was constructed to determine the accumulation time. The same things were done to $\mathrm{Cu}(\mathrm{II})$, $\mathrm{Pb}(\mathrm{II})$ and $\mathrm{Zn}(\mathrm{II})$.

\section{Determination of the Relative Standard Deviation}

$10 \mathrm{~mL}$ standard solution of $10 \mu \mathrm{g} / \mathrm{L} \mathrm{Cd(II)}$ and $10 \mathrm{~mL}$ of $0.1 \mathrm{M} \mathrm{KCl}$ were put into voltammetric vessel, $\mathrm{pH}$ was adjusted to 7.0 by addition of $\mathrm{NH}_{4} \mathrm{OH}$, then was added $0.3 \mathrm{~mL}$ of $0.5 \mathrm{mM}$ calcon, deposition potential $-0.7 \mathrm{~V}$ and the accumulation time $70 \mathrm{sec}$. Performed measurements with repetition as much as 8 times. The same things were done for $\mathrm{Cu}(\mathrm{II}), \mathrm{Pb}(\mathrm{II})$ and $\mathrm{Zn}(\mathrm{II})$ [18-19].

\section{Application Method}

The sample used in this study taken in the form of sea water around Bungus, Padang City. Samples taken were preserved with $65 \% \mathrm{HNO}_{3}$ with a ratio of 1:1000.

\section{RESULT AND DISCUSSION}

In this study the determination of $\mathrm{Cd}(\mathrm{II}), \mathrm{Cu}(\mathrm{II})$ $\mathrm{Pb}(\mathrm{II})$ and $\mathrm{Zn}(\mathrm{II})$ by adsorptive stripping voltammetry (ASV) was conducted. The optimum measurement conditions were required for measurement. Therefore several parameters namely; variation supporting electrolyte $\left(\mathrm{NH}_{4} \mathrm{Cl}\right.$ and $\left.\mathrm{KCl}\right)$, complexing agent variations include: APDC, DMG, and oxine calcon, variations in the concentration of complex optimum (calcon), $\mathrm{pH}$ of solution, accumulation potential and accumulation time variations were studied.

\section{Variations supporting electrolyte}

The influence of supporting electrolyte $0.1 \mathrm{M} \mathrm{NH}_{4} \mathrm{Cl}$ and $0.1 \mathrm{M} \mathrm{KCl}$ against the peak current (Ip) for the metals $\mathrm{Cd}(\mathrm{II}), \mathrm{Cu}(\mathrm{II}), \mathrm{Pb}(\mathrm{II})$ and $\mathrm{Zn}(\mathrm{II})$ with the potential accumulation of $-0.7 \mathrm{~V}$, deposition time $60 \mathrm{sec}, 0.3 \mathrm{~mL}$ of $1 \mathrm{mM}$ calcon were shown in Table 1.

The addition of supporting electrolyte serves as to conduct electrical current in the solution so that the analyte is not affected by a given difference of potential changes rapidly. In addition, to suppress the flow of migration, controlling the potential for reduced solution resistance as well as keeping the total ionic strength constant $[8,11]$. At the table, it is showed that the addition of supporting electrolyte $0.1 \mathrm{M} \mathrm{NH}_{4} \mathrm{Cl}$ and $0.1 \mathrm{M}$ $\mathrm{KCl}$ against the flow generated peak for $\mathrm{Cd}(\mathrm{II})$ there is a little difference of $0.003 \mu \mathrm{A}$, while for the metal ions $\mathrm{Cu}(\mathrm{II})$,
Table 1. The relationship between the variation of supporting electrolyte on the peak current (Ip)

\begin{tabular}{ccccc}
\hline $0.1 \mathrm{M}$ & \multicolumn{4}{c}{ Peak Current (Ip) } \\
\cline { 2 - 5 } $\begin{array}{c}\text { Supporting } \\
\text { Electrolyte }\end{array}$ & $\begin{array}{c}\mathrm{Cd}(\mathrm{II}) \\
(\mu \mathrm{A})\end{array}$ & $\begin{array}{c}\mathrm{Cu}(\mathrm{II}) \\
(\mu \mathrm{A})\end{array}$ & $\begin{array}{c}\mathrm{Pb}(\mathrm{II}) \\
(\mu \mathrm{A})\end{array}$ & $\begin{array}{c}\mathrm{Zn}(\mathrm{II}) \\
(\mu \mathrm{A})\end{array}$ \\
\hline $\mathrm{NH}_{4} \mathrm{Cl}$ & 0.075 & 11.550 & 0.013 & 15.510 \\
$\mathrm{KCl}$ & 0.078 & 33.790 & 0.021 & 48.320 \\
\hline
\end{tabular}

Table 2. Effect of variation the complexing agent on peak current (Ip)

\begin{tabular}{ccccc}
\hline Variation of & \multicolumn{4}{c}{ Peak current $(\mathrm{Ip})$} \\
the & $\mathrm{Cd}(\mathrm{II})$ & $\mathrm{Cu}(\mathrm{II})$ & $\mathrm{Pb}(\mathrm{II})$ & $\mathrm{Zn}(\mathrm{II})$ \\
complex & $(\mu \mathrm{A})$ & $(\mu \mathrm{A})$ & $(\mu \mathrm{A})$ & $(\mu \mathrm{A})$ \\
\hline APDC & 0.004 & $\mathrm{Nd}$ & $\mathrm{Nd}$ & 36.470 \\
DMG & 0.062 & 29.520 & 1.580 & 29.690 \\
Calcon & 0.078 & 33.800 & 1.740 & 48.460 \\
Oxine & 0.040 & 0.022 & 0.020 & $\mathrm{Nd}$ \\
\hline
\end{tabular}

$\mathrm{Nd}=$ Not detected

$\mathrm{Pb}$ (II) and $\mathrm{Zn}$ (II) with the addition of supporting electrolyte $0.1 \mathrm{M} \mathrm{NH}_{4} \mathrm{Cl}$ and $0.1 \mathrm{M} \mathrm{KCl}$ there were significant differences. The resulting peak flow for the third highest on the metal ions is to use a $0.3 \mathrm{M} \mathrm{KCl}$. This is because $\mathrm{K}^{+}$ions are smaller than the ion $\mathrm{NH}_{4}{ }^{+}$, so its speed to overcome the movement of ions in solution (electro migration) is much greater than $\mathrm{NH}_{4}{ }^{+}$ ion. As a result, the peak current generated using $\mathrm{KCl}$ as the supporting electrolyte is much greater than using $\mathrm{NH}_{4} \mathrm{Cl}$. For subsequent studies $0.1 \mathrm{M} \mathrm{KCl}$ was used as supporting electrolyte.

\section{Variations complexing agent}

Ammonium pyrrolydine dithiocarbamate (APDC), dimethyl glyoxime (DMG), oxine and calcon serves as a complexing agents, giving effect to the voltammogram of $\mathrm{Cd}(\mathrm{II}), \mathrm{Cu}(\mathrm{II}), \mathrm{Pb}(\mathrm{II})$ and $\mathrm{Zn}(\mathrm{II})$. Effects may be studied by comparing the peak current generated from metal complexes with the complexing agents mentioned above. The measurement results can be seen in Table 2. Measurements were made with the same complex concentration of $1 \mathrm{mM}, 60 \mathrm{sec}$ accumulation time, accumulation potential -0.7 volts in $0.5 \mathrm{~mL}$ of $0.1 \mathrm{M} \mathrm{KCl}$ at $\mathrm{pH}: 7.0: 6.0: 4.0$ and $\mathrm{pH} 3.6$ for $\mathrm{Cd}(\mathrm{II}), \mathrm{Cu}(\mathrm{II}), \mathrm{Pb}(\mathrm{II})$ and $\mathrm{Zn}(\mathrm{II})$.

Table 2 shows that the metal ions $\mathrm{Cd}(\mathrm{II}), \mathrm{Cu}(\mathrm{II})$, $\mathrm{Pb}(\mathrm{II})$ and $\mathrm{Zn}(\mathrm{II})$ can be detected with the use calcon as complex, which giving the highest peak current, its value in a row $77.590 \mu \mathrm{A}, 33.800 \mu \mathrm{A}, 1.740 \mu \mathrm{A}$ and $48.460 \mu \mathrm{A}$. $\mathrm{Cd}(\mathrm{II}), \mathrm{Cu}(\mathrm{II}), \mathrm{Pb}(\mathrm{II})$ and $\mathrm{Zn}(\mathrm{II})$ can form complexes with dimethyl glyoxime (DMG), the resulting peak current $0.062 \mu \mathrm{A}, 29.520 \mu \mathrm{A}, 1.580 \mu \mathrm{A}$ and $29.690 \mu \mathrm{A}$, the current generated were smaller than calcon used as complexing agent. The use of APDC as a complexes agent did not provide the peak current (not detectable) especially for $\mathrm{Cu}(\mathrm{II})$ and $\mathrm{Pb}(\mathrm{II})$, this is 


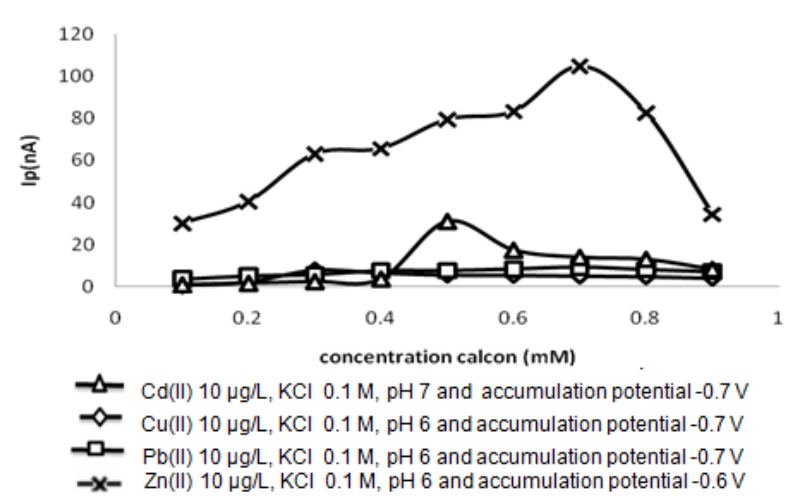

Fig 1. The effect of calcon concentration on peak current

due to APDC does not form complexes with $\mathrm{Cu}(\mathrm{II})$ and $\mathrm{Pb}(\mathrm{II})$. However, $\mathrm{Zn}(\mathrm{II})$ forming complexes with APDC which produced a peak current of $36.47 \mu \mathrm{A}$ can be seen in Table 2. The use of oxine as complexing agent results in peak current $0.040 \mu \mathrm{A}, 0.220 \mu \mathrm{A}, 0.020 \mu \mathrm{A}$ and undetectable, respectively for the metal ions $\mathrm{Cd}(\mathrm{II})$, $\mathrm{Cu}(\mathrm{II}), \mathrm{Pb}$ (II) and $\mathrm{Zn}(\mathrm{II})$. Metal ions $\mathrm{Pb}$ (II) and $\mathrm{Zn}(\mathrm{II})$ produced very small currents, even though ions $\mathrm{Zn}$ (II) peak current produced is not detected. It means here that oxine did not form complexes with $\mathrm{Pb}$ (II) or with $\mathrm{Zn}$ (II). From the results shown in Table 2, calcon was chosen as the optimum complexing agent. For subsequent studies calcon was used as a complexing agent,

\section{Variation of calcon concentration}

In this study the relationship between the concentration calcon with peak current of a standard solution of $\mathrm{Cd}(\mathrm{II}), \mathrm{Cu}(\mathrm{II}), \mathrm{Pb}(\mathrm{II})$ and $\mathrm{Zn}(\mathrm{II})$ each $10 \mu \mathrm{g} / \mathrm{L}$ with a potential accumulation $-0.7 \mathrm{~V}$ to $\mathrm{Cd}(\mathrm{II}), \mathrm{Cu}(\mathrm{II})$, $\mathrm{Pb}$ (II) and $-0.6 \mathrm{~V}$ for $\mathrm{Zn}(\mathrm{II})$, accumulation time $60 \mathrm{sec}, \mathrm{pH}$ 7 for $\mathrm{Cd}(\mathrm{II})$ and $\mathrm{pH} 6$ for $\mathrm{Cu}(\mathrm{II}), \mathrm{Pb}(\mathrm{II})$ and $\mathrm{Zn}(\mathrm{II})$ was determined. The concentration variation calcon in $20 \mathrm{~mL}$ of test solution were $0.1 \mathrm{mM}, 0.2 \mathrm{mM}, 0.3 \mathrm{mM}, 0.4 \mathrm{mM}$, $0.5 \mathrm{mM}, 0.6 \mathrm{mM}, 0.7 \mathrm{mM}, 0.8 \mathrm{mM}$ and $0.9 \mathrm{mM}$. The result can be seen in Fig. 1.

Fig. 1 shows that the peak current increased with increasing concentration below $0.4 \mathrm{mM}$ calcon for $\mathrm{Cu}(\mathrm{II})$ and $0.5 \mathrm{mM}$ for $\mathrm{Cd}(\mathrm{II})$. This happened because there were still $\mathrm{Cd}(\mathrm{II})$ and $\mathrm{Cu}$ (II) that did not yet form complex with calcon. At concentrations above $0.5 \mathrm{mM}$ calcon a decline in peak current existed. This is due to the occurrence of competition between the ligand absorbed on the electrode surface at deposition step (preconcentration) and forming complexes with metal ions. Peak currents generated as a result of reduction of metal-ligand complexes absorbed on the surface of the working electrode at stripping step. The peak current generated depended upon calcon concentration used. At higher calcon concentration, it was difficult the metal-

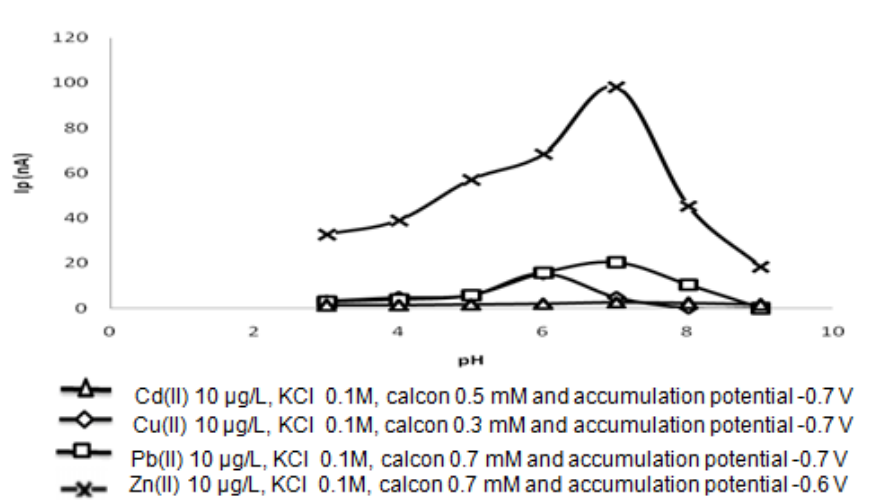

Fig 2. The effect of $\mathrm{pH}$ on peak current

ligand complex to be reduced so that the resulting peak current getting smaller. As for $\mathrm{Pb}$ (II) and $\mathrm{Zn}$ (II) an increase in the peak current at calcon concentration $0.1 \mathrm{mM}-0.7 \mathrm{mM}$, indicated the formation of complexes of $\mathrm{Pb}(\mathrm{II})$ with calcon or $\mathrm{Zn}(\mathrm{II})$ with increasing calcon. At concentrations above $0.7 \mathrm{mM}$ calcon, a decline in peak current made possible the competition between complexing agent as a ligand in binding to metal ions so that the current decreased. For that reason, calcon at $0.5 \mathrm{mM}$ concentration was chosen as the optimum conditions for $\mathrm{Cd}(\mathrm{II}), 0.3 \mathrm{mM}$ for $\mathrm{Cu}(\mathrm{II})$, while $0.7 \mathrm{mM}$ for $\mathrm{Pb}(\mathrm{II})$ and $\mathrm{Zn}(\mathrm{II})$. At the optimum concentration, metal ions and complexing agent (calcon) formed a complete complex so as to provide optimum current.

\section{Variation of $\mathrm{pH}$}

The complex formation between the $\mathrm{Cd}(\mathrm{II}), \mathrm{Cu}(\mathrm{II})$, $\mathrm{Pb}$ (II) ions and $\mathrm{Zn}$ (II) ions with calcon at deposition (pre-concentration) step were affected by $\mathrm{pH}$. At the proper $\mathrm{pH}$ it was expected more and more Cd-calcon, $\mathrm{Cu}$-calcon, $\mathrm{Pb}$-calcon and $\mathrm{Zn}$-calcon complexes formed at the electrode surface so that they would produce high peak current at the time of measurement. Effect of $\mathrm{pH}$ on peak current (Ip) was studied for a standard solution of $\mathrm{Cd}(\mathrm{II}), \mathrm{Cu}(\mathrm{II}), \mathrm{Pb}(\mathrm{II})$ and $\mathrm{Zn}(\mathrm{II})$ at a concentration of $10 \mu \mathrm{g} / \mathrm{L}$ each, by varying the $\mathrm{pH}$ of 5 - 9. Fig. 2 shows that the peak currents are influenced by $\mathrm{pH}$ for each metal ion. At $\mathrm{pH} 3$ to $\mathrm{pH} 6$, $\mathrm{Cu}(\mathrm{II})$ produced increasing peak currents, while ions $\mathrm{Cd}(\mathrm{II}), \mathrm{Pb}(\mathrm{II})$ and $\mathrm{Zn}(\mathrm{II})$ increased to $\mathrm{pH}$ 7. This was because with increasing $\mathrm{pH}$ of the solution, there were more $\mathrm{Cd}(\mathrm{II}), \mathrm{Cu}(\mathrm{II}), \mathrm{Pb}(\mathrm{II})$ and $\mathrm{Zn}(\mathrm{II})$ in the form of free ions. As a result, the ions were trapped on the surface of the working electrode forming metal-calcon complex, so that the resulting peak currents increased. The $\mathrm{pH}$ also affects the stability of the complex formed, and also affected the concentration of analyte deposited on the working electrode, increasing peak current generated. High peak current occurs at pH 6 optimum 


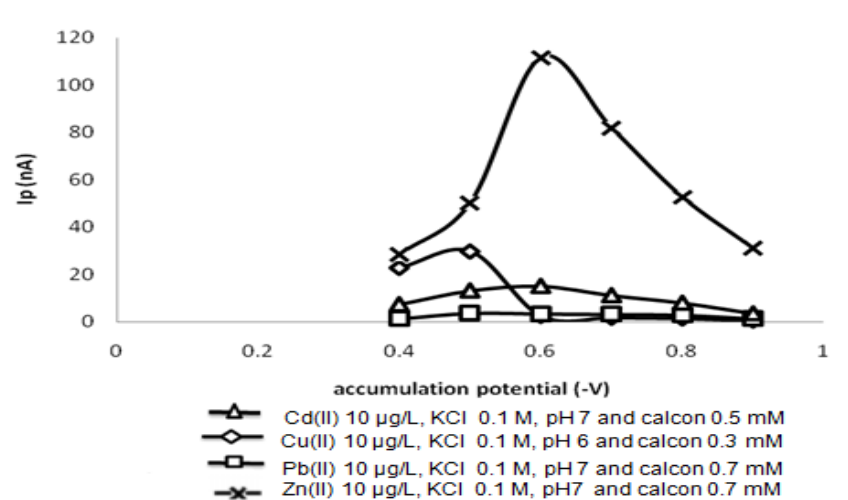

Fig 3. The effect of accumulation potential on peak current

for ion $\mathrm{Cu}(\mathrm{II})$ and $\mathrm{pH} 7$ for $\mathrm{Cd}(\mathrm{II}), \mathrm{Pb}(\mathrm{II})$ and $\mathrm{Zn}(\mathrm{II})$, because at these $\mathrm{pH}$, there were many metal ions in the form of free ions, so that many $\mathrm{Cd}(\mathrm{II}), \mathrm{Cu}(\mathrm{II}), \mathrm{Pb}(\mathrm{II})$ and $\mathrm{Zn}$ (II) got trapped on the electrode surface thus forming complexes with calcon.

At $\mathrm{pH} 7$ to $\mathrm{pH} 9$ with a peak current decreased, this was due to complex formation between the ions $\mathrm{Cd}(\mathrm{II})$, $\mathrm{Cu}(\mathrm{II}), \mathrm{Pb}(\mathrm{II})$ and $\mathrm{Zn}(\mathrm{II})$ with calcon disturbed by $\mathrm{OH}^{-}$ions becoming more and more in solution with increasing $\mathrm{pH}$. At high $\mathrm{pH}$ the metal ions would be more dominant $\mathrm{OH}^{-}$ ions reacting to form metal hydroxide, which reacted with calcons reduced. At a certain $\mathrm{pH}$ the metal ions formed precipitated as its hydoxides and, consequently resulting smaller current.

\section{Variation of accumulation potential}

In this study the determination of the relationship between the accumulation potential with peak current of $\mathrm{Cd}(\mathrm{II}), \mathrm{Cu}(\mathrm{II}), \mathrm{Pb}(\mathrm{II})$ and $\mathrm{Zn}(\mathrm{II})$ was examined in the range $-0.4 \mathrm{~V}$ to $-0.9 \mathrm{~V}$. Accumulation potential is the potential at the time of analyte deposited on the working electrode. The result can be seen in Fig. 3.

Curve shows that in every variation of accumulation potential tested, it gave a different value of peak current. For $\mathrm{Cd}(\mathrm{II})$ and $\mathrm{Zn}(\mathrm{II})$ at a potential of $-0.4 \mathrm{~V}$ to $-0.6 \mathrm{~V}$ peak current produced was increasing, while for the ions $\mathrm{Cu}(\mathrm{II})$ and $\mathrm{Pb}(\mathrm{II})$ in the range of potential -0.4 $\mathrm{V}$ to $-0.5 \mathrm{~V}$. In the potential range -0.6 to $-0.9 \mathrm{~V}$ curve dropped down significantly, especially for $\mathrm{Cu}(\mathrm{II})$. This suggests a process of deposition (accumulation) of the analyte complex on the surface of the working electrode which reaches a maximum at $-0.5 \mathrm{~V}$ to $\mathrm{Cu}(\mathrm{II})$ and $\mathrm{Pb}(\mathrm{II})$ and $-0.6 \mathrm{~V}$ to $\mathrm{Cd}(\mathrm{II})$ and $\mathrm{Zn}(\mathrm{II})$. For $\mathrm{Cd}(\mathrm{II})$ and $\mathrm{Zn}(\mathrm{II})$ can be seen from Fig. 3, at a potential of $-0.4 \mathrm{~V}$ to $-0.6 \mathrm{~V}$ the curve rose with a relatively small increase for the ions $\mathrm{Cd}(\mathrm{II})$, whereas for $\mathrm{Zn}(\mathrm{II})$ the increase curve (peak current) was large enough. At $-0.5 \mathrm{~V}$ potential was optimum accumulation potential for $\mathrm{Cu}(\mathrm{II})$ and $\mathrm{Pb}(\mathrm{II})$, while for $\mathrm{Cd}(\mathrm{II})$ and $\mathrm{Zn}(\mathrm{II})-0.6 \mathrm{~V}$, because the peak

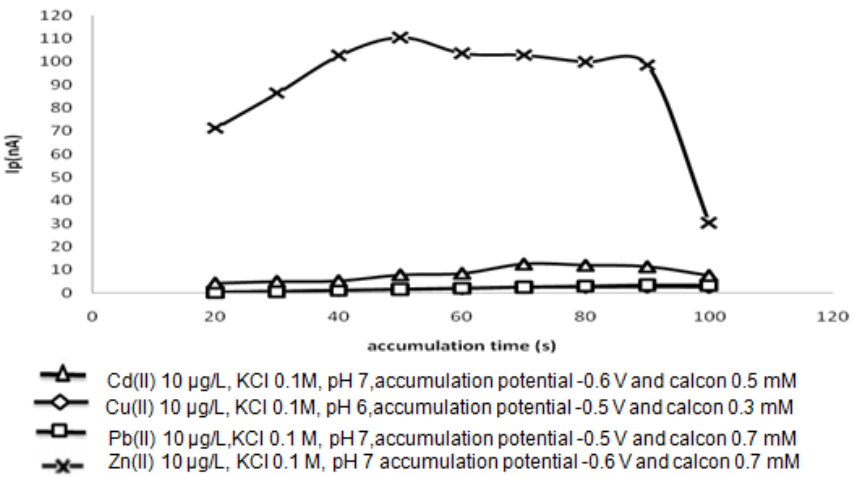

Fig 4. The relationship between the accumulation time on peak current

currents was generated at the maximum. At potential $0.7 \mathrm{~V}$ current reduced, this was caused by reduction of analyte complex during deposition process [8].

\section{Variation of accumulation time}

Accumulation time is the time when the analyte accumulated or deposited on the surface of the working electrode in the form of Hanging Mercury Drop Electrode (HMDE). Effect on the deposition time during the accumulation step (pre-concentration). At the accumulation time pre-concentration was useful to improve sensitivity and lower detection limits $[8,11]$. The time of accumulation of $\mathrm{Cd}(\mathrm{II}), \mathrm{Cu}(\mathrm{II}), \mathrm{Pb}$ (II) and $\mathrm{Zn}$ (II) affected the stability of the complex formed on the electrode surface. The study carried out the determination of the relationship between accumulation times with peak currents that were tested, by varying the accumulation time as follows: $20,30,40,50,60$, $70,80,90$ and $100 \mathrm{sec}$. The result can be seen in Fig.4.

Fig. 4, shows that the accumulation time affected peak currents of $\mathrm{Cd}(\mathrm{II}), \mathrm{Cu}(\mathrm{II}), \mathrm{Pb}(\mathrm{II})$ and $\mathrm{Zn}(\mathrm{II})$. The increase in accumulation time increased the peak current, since $\mathrm{Cd}(\mathrm{II}), \mathrm{Cu}(\mathrm{II}), \mathrm{Pb}(\mathrm{II})$ and $\mathrm{Zn}(\mathrm{II})$ ions bonded to calcon accumulated on the working electrode increased until they finally saturated.

At the time of accumulation, measurements with $20 \mathrm{sec}$ to $60 \mathrm{sec}$ increasing the peak current was not so great, especially for the peak current $\mathrm{Cd}(\mathrm{II}), \mathrm{Cu}(\mathrm{II})$. and $\mathrm{Pb}(\mathrm{II})$ because the ions $\mathrm{Cd}(\mathrm{II}), \mathrm{Cu}(\mathrm{II})$ and $\mathrm{Pb}(\mathrm{II})$ that accumulated at the working electrode was still small. The peak current on accumulation time of 70 to $90 \mathrm{sec}$ increased slightly. At accumulation time of 90 $\mathrm{sec}$, the peak current increased significantly, especially for the $\mathrm{Cu}(\mathrm{II})$ and $\mathrm{Pb}(\mathrm{II})$ ions. Time of $90 \mathrm{sec}$ was chosen as the optimum accumulation time for the next determination of ion $\mathrm{Cu}(\mathrm{II})$ and $\mathrm{Pb}(\mathrm{II})$, while for $\mathrm{Cd}(\mathrm{II})$ it was $70 \mathrm{sec}$. Accumulation time of more than $90 \mathrm{sec}$ did not increase the peak current, whereas, it, otherwise, 
even decreased. Longer accumulation time would cause saturation of electrode $[8,11]$.

In Fig. 4, it can also be seen that the accumulation of 20 to $50 \mathrm{sec}$ the peak current produced by $\mathrm{Zn}$ (II) was quite high when compared with the other three metal ions. It meant that quite large $\mathrm{Zn}(\mathrm{II})$ accumulated at the working electrode so that the current increased. At the accumulation time of more than $50 \mathrm{sec}$ did not increase in peak current, even it tended to decrease. This happened because of the working electrode where the process of accumulation has been saturated so that the resulting current also decreased. Accumulation time of $50 \mathrm{sec}$ was used as the optimum accumulation time for the determination of $\mathrm{Zn}(\mathrm{II})$ hereinafter.

\section{Relative standard deviation (RSD)}

The relative standard deviation shows the precision of the method at the same operating conditions. The determination of the relative standard deviation performed at optimum conditions have been defined above. At the optimum conditions with 8 times replicates $(n=8)$ measurements of $10 \mu \mathrm{g} / \mathrm{L}$ standard solution $\mathrm{Cd}(\mathrm{II}), \mathrm{Cu}(\mathrm{II}), \mathrm{Pb}(\mathrm{II})$ and $\mathrm{Zn}(\mathrm{II})$ were $7.80 \%, 4.25 \%$, $8.70 \%$ and $0.86 \%$. The result can be seen in Table 3 .

According to the AOAC method, the value of relative standard deviation was smaller than $8 \%$ at concentration of $10 \mu \mathrm{g} / \mathrm{L}$. That means this method has a high degree of precision because the RSD obtained for each metals was smaller than $8 \%$, except for $\mathrm{Pb}(\mathrm{II})$ that was greater than $8 \%$.

\section{Recovery}

To determine the level of accuracy of this method, it was necessary to determine the value of recovery. Samples of known concentration were added the number of standard solution, and then compared with the concentrations of samples and standards added. In this study the recovery of sea water samples studied was taken from Bungus, Padang City. The results of recovery of $\mathrm{Cd}(\mathrm{II}), \mathrm{Cu}(\mathrm{II}), \mathrm{Pb}(\mathrm{II})$ and $\mathrm{Zn}(\mathrm{II})$ by adsorptive stripping voltammetry at the optimum conditions, its value obtained were $98.68 \%, 97.99 \%, 96.17 \%$ and $99.96 \%$, respectively.

According to the AOAC method, the percent recovery for the solution with the concentration of $50 \mu \mathrm{g} / \mathrm{L}$ was in the range of $70 \%-110 \%$. That is, this method has high accuracy [18].

This method were applied to the determination of $\mathrm{Cd}(\mathrm{II}), \mathrm{Cu}(\mathrm{II}), \mathrm{Pb}(\mathrm{II})$ and $\mathrm{Zn}(\mathrm{II})$ in seawater around the waters of Bungus, Padang City, using the optimum conditions for measurement that had been obtained for each metal ion them. Measurements were conducted by standard addition method. The concentration obtained for
Table 3. Measurement results of $10 \mu \mathrm{g} / \mathrm{L} \mathrm{Cd(II),} \mathrm{Cu(II),}$ $\mathrm{Pb}(\mathrm{II})$ and $\mathrm{Zn}(\mathrm{II})$

\begin{tabular}{ccccc}
\hline Replicates & \multicolumn{4}{c}{ Peak current $(\boldsymbol{\mu} \mathbf{A})$} \\
\cline { 2 - 5 } 1 & $\mathbf{C d}(\mathrm{II})$ & $\mathbf{C u}(\mathrm{II})$ & $\mathbf{P b}(\mathrm{II})$ & $\mathbf{Z n}(\mathrm{II})$ \\
1 & 4.260 & 46.360 & 4.710 & 73.340 \\
\hline 2 & 4.750 & 47.310 & 5.170 & 73.370 \\
3 & 4.740 & 46.150 & 4.220 & 72.810 \\
4 & 4.020 & 41.700 & 3.990 & 71.410 \\
5 & 4.360 & 44.290 & 4.130 & 73.200 \\
6 & 5.140 & 45.500 & 4.490 & 73.090 \\
7 & 4.830 & 45.020 & 4.460 & 72.960 \\
8 & 4.500 & 47.880 & 4.150 & 72.790 \\
Average & 4.575 & 45.526 & 4.415 & 72.871 \\
SD & 0.3588 & 1.9358 & 0.3844 & 0.6299 \\
RSD & $7.80 \%$ & $4.25 \%$ & $8.70 \%$ & $0.86 \%$ \\
\hline
\end{tabular}

$\mathrm{Cd}(\mathrm{II}), \mathrm{Cu}(\mathrm{II}), \mathrm{Pb}(\mathrm{II})$ and $\mathrm{Zn}(\mathrm{II})$ in seawater samples Bungus, Padang City were $13.200 \mu \mathrm{g} / \mathrm{L} ; 0.089 \mu \mathrm{g} / \mathrm{L}$; $17.163 \mu \mathrm{g} / \mathrm{L}$ and $62.000 \mu \mathrm{g} / \mathrm{L}$, respectively.

\section{CONCLUSION}

It can be concluded that the optimum conditions for measurement of $\mathrm{Cd}(\mathrm{II}), \mathrm{Cu}(\mathrm{II}), \mathrm{Pb}(\mathrm{II})$ and $\mathrm{Zn}(\mathrm{II})$ by adsorptive stripping voltammetry were: $0.1 \mathrm{M} \mathrm{KCl}$ as optimum supporting electrolyte, calcon as the optimum complexing agent. Calcon optimum concentration obtained for $\mathrm{Cd}(\mathrm{II}) 0.5 \mathrm{mM}, \mathrm{Cu}(\mathrm{II}) 0.3 \mathrm{mM}$ while $0.7 \mathrm{mM}$ for $\mathrm{Pb}(\mathrm{II})$ and $\mathrm{Zn}(\mathrm{II})$, at $\mathrm{pH} 7$ for $\mathrm{Cd}(\mathrm{II}), \mathrm{Pb}(\mathrm{II})$ and $\mathrm{Zn}(\mathrm{II})$, whereas for $\mathrm{Cu}(\mathrm{II})$ at $\mathrm{pH} 6$, the accumulation potential $0.5 \mathrm{~V}$ for $\mathrm{Cu}(\mathrm{II})$ and $\mathrm{Pb}(\mathrm{II})$, while $-0.6 \mathrm{~V}$ for $\mathrm{Cd}$ (II) and $\mathrm{Zn}$ (II) and the accumulation time of $\mathrm{Cd}$ (II) $70 \mathrm{~s}, \mathrm{Cu}(\mathrm{II})$ and $\mathrm{Pb}$ (II) $90 \mathrm{sec}$ while the $\mathrm{Zn}$ (II) 50 sec. At the optimum conditions, the relative standard deviation was obtained with 8 replicates $(n=8)$ measurements standard solution $\mathrm{Cd}(\mathrm{II}), \mathrm{Cu}(\mathrm{II}), \mathrm{Pb}(\mathrm{II})$ and $\mathrm{Zn}(\mathrm{II})$ $10 \mu \mathrm{g} / \mathrm{L}$ were: $7.80 \%, 4.25 \%, 8.70 \%$ and $0.86 \%$, respectively. This method was applied to the determination of $\mathrm{Cd}(\mathrm{II}), \mathrm{Cu}(\mathrm{II})$ and $\mathrm{Pb}(\mathrm{II})$ directly in seawater waters of Bungus, Padang City. The concentration obtained were: $13.200 \mu \mathrm{g} / \mathrm{L}$ for $\mathrm{Cd}(\mathrm{II})$, $17.100 \mu \mathrm{g} / \mathrm{L}$ for $\mathrm{Cu}(\mathrm{II}), 0.089 \mu \mathrm{g} / \mathrm{L}$ for $\mathrm{Pb}(\mathrm{II})$, while for $\mathrm{Zn}$ (II) $62.000 \mu \mathrm{g} / \mathrm{L}$ with a recovery value (Recovery) for each $\mathrm{Cd}(\mathrm{II}), \mathrm{Cu}(\mathrm{II}), \mathrm{Pb}(\mathrm{II})$ and $\mathrm{Zn}(\mathrm{II})$ were $98.68 \%$, $97.99 \%, 96.17 \%$ and $99.96 \%$, respectively.

\section{ACKNOWLEDGEMENT}

We express our gratitude to 1) Directorate General of Higher Education, Ministry of National Education who has funded this research in accordance with the Letter Agreement Implementation of Fundamental Research Assignment Number: 169/SP2H/PL/Dit.Litmas/IV/2011, April 14, 2011 and 2) Research Institute of the University of Andalas which 
has facilitated the study so that it underwent according to schedule.

\section{REFERENCES}

1. Sanusi, H.S., Syamsu, S., and Sardjirun, S.,1985, The content and distribution of heavy metals in various marine fish commodities are transmitted through the TPI Fish Market Jakarta, Thesis, Faculty of Fisheries, Bogor Agricultural Institute.

2. Hutagalung, H.P., 1991, Marine pollution by heavy metals, status of marine pollution in Indonesia.

3. Deswati and Abdullah, Z., 2006, The use of sand filters in order to improve water quality and minimize the content of heavy metals in the waters of Central Coast Fish Seed (BBIP) Teluk Buo, Research Report Research Project Grant TPSDP Unand/VII.

4. Amini, M.K., and Kabiri, M., 2005, J. Iranian Chem. Soc., 2, 1, 32-39.

5. Ensafi, A.A., Abbasi, S., Manour, H.R., and Baltork, I.M., 2001, Anal. Sci., 17, 2, 609-612.

6. Zang. S., and Huang, W., 2001, Anal. Sci., 17, 983985.

7. Mondragon, R.M., Baeza, A., and Ibanez, J.G., 2002, Anal. Sci., 18, 2, 191-193.

8. Wang, J., 2000, Analytical Electrochemistry, $2^{\text {nd }}$ ed., A John Willey and Sons, Inc., 81-84 and 108-110.

9. Deswati; Suyani, H., and Safni., 2011, The development of analysis method of $\mathrm{Cd}, \mathrm{Cu}, \mathrm{Pb}$ and $\mathrm{Zn}$ in the sea water with simultaneous by adsorptive stripping voltammetry (ASV), Research Report of Fundamental.

10. Pudjaatmaka, A.H. and Meity, T.Q., 2004, Dictionary of Chemistry, Hall Book, Jakarta, 356.

11. Proti, P., 2001, Introduction to Modern Voltammetric and Polarographic Analysis Techniques, $4^{\text {th }}$ ed., Amel Electrochemistry, 2-4 and 21-26.

12. Deswati., 2008, Optimization studies in the determination of nickel (II) by adsorptive stripping voltammetry, DIPA Independent Fund Research Report Andalas University, Padang.

13. Cobelo-Gracia, A., Santos-Echeandia, J., Prego, R., and Nieto, O., 2005, Electroanalysis, 17, 10, 906-911.

14. Deswati, Suyani, Imelda, H., and Yulia., 2009, Jurnal Riset Kimia, 3, 1, 22-30.

15. Jugade, R., and Joshi, A.P., 2006, Anal. Sci., 22, 4, 571-574.

16. Babaei, A; Sham, E., and Samadzadeh, A., 2006, Anal. Sci., 22, 7, 955-956.

17. Shemirani, F., Rajabi, M., Asghari, A., MilaniHosseini, R., 2005, Can. J. Anal. Sci. Spectros., 50, 4, 175-181.

18. Anonymous, 2002, AOAC Guidelines for Single Laboratory,

http://www.aoac.org/official_methods/slv_guideline s.pdf, accessed on July 4, 2011.

19. Anderson, R.L., 1987, Practical statistics for analytical chemistry, Norstran Van Reinhold Company. 